\title{
Performance of natural and modified smectite - kinetic and thermodynamics involving arsenic (V) adsorption
}

\section{(Desempenho de esmectita natural e modificada - cinética e termodinâmica envolvendo adsorção de arsênio (V))}

\author{
D. L. Guerra ${ }^{1}$, C.Airoldi ${ }^{1}$, R. R. Viana ${ }^{2}$ \\ ${ }^{1}$ Instituto de Química, Universidade Estadual de Campinas - UNICAMP, C.P. 6154, Campinas, SP 13084-971 \\ ${ }^{2}$ Centro de Recursos Minerais, Universidade Federal de Mato Grosso - UFMT, Cuiabá, MT \\ dlguerra@iqm.unicamp.br
}

\begin{abstract}
A natural smectite sample has been modified by organofunctionalization process using synthetic route involved the reaction of 2-mercaptopyrimidine with 3-chloropropyltriethoxysilane. The resulting material $\left(\mathrm{S}_{\mathrm{MPY}}\right)$ was characterized by SEM, FTIR, textural analysis and ${ }^{29} \mathrm{Si}$ MAS-NMR. The ability of this material to removed As (V) from aqueous solution was followed by series of adsorption isotherms adjusted to the Langmuir equation at room temperature and $\mathrm{pH}$ 2.0. The kinetic parameters analyzed by Lagergren and Elovich models gave a good fit for a pseudo-second order reaction with $\mathrm{k}_{2}$ in the 4.9 to $14.0 \mathrm{mmol}^{-1} \mathrm{~min}^{-1}$ range for $\mathrm{S}_{\mathrm{MPY}}$. The adsorption process was exothermic $\left(\Delta_{\text {int }} \mathrm{H}=-4.09\right.$ to $\left.-5.79 \mathrm{~kJ} \cdot \mathrm{mol}^{-1}\right)$ accompanied by increase in entropy $\left(\Delta_{\text {int }} \mathrm{S}=41.29\right.$ to $\left.61.80 \mathrm{JK}^{-1} \cdot \mathrm{mol}^{-1}\right)$ and Gibbs energy $\left(\Delta_{\text {int }} \mathrm{G}=-22.34\right.$ to $\left.-24.19 \mathrm{kJmol}^{-1}\right)$. The energetic effect caused by arsenic cation adsorption was determined through calorimetric titration at the solid-liquid interface and gave a net thermal effect that enabled the calculation of the exothermic values and the equilibrium constant.
\end{abstract}

Keywords: adsorption, smectite, kinetic, thermodynamic, arsenic.

\section{Resumo}

Uma amostra de esmectita natural foi modificada por processo de organofuncionalização usando rota sintética, envolvendo a reação de 2-mercaptopirimidina com 3-cloropropiltrietoxisilano. $O$ material resultante $\left(S_{M P Y}\right)$ foi caracterizado por microscopia eletrônica de varredura, espectroscopia de infravermelho com transformada de Fourier, análise textural e ${ }^{29} \mathrm{Si}$ MAS-NMR. A habilidade deste material para remover As (V) a partir de solução aquosa foi investigada por series de isotermas ajustadas pela equação de Langmuir em temperatura ambiente e pH 2,0. Os parâmetros cinéticos foram analisados por modelos de Lagergren e Elovich, em que um bom ajuste foi obtido para o modelo de reação de pseudo-segunda ordem com $k_{2}$ em 4,9 para $14,0 \mathrm{mmol}^{-1} \mathrm{~min}^{-1}$ para $S_{M P Y}$ O processo de adsorção foi exotérmico $\left(\Delta_{\text {int }} H=-4,09\right.$ to $\left.-5,79 \mathrm{kJmol}^{-1}\right)$ acompanhado por aumento de entropia $\left(\Delta_{\text {int }} S=41,29\right.$ to 61,80 $\left.J^{-1} \mathrm{~mol}^{-1}\right)$ e energia livre de Gibbs $\left(\Delta_{\text {int }} G=-22,34\right.$ to $\left.-24,19 \mathrm{kJmol}^{-1}\right)$. O efeito energético causado pela adsorção do cátion de arsênio foi determinado através de ensaios calorimétricos na interface que permitisse o cálculo dos valores exotérmicos e da constante de equilíbrio.

Palavras-chave: adsorção, esmectita, cinética, termodinâmica, arsênio.

\section{INTRODUCTION}

Arsenic is a toxic pollutant and poses a serious health risk in many countries of the world. Different technologies have been developed to remove arsenic from both water and wastewater. Technologies include the conventional process of oxidation, co-precipitation and adsorption onto coagulated flocs, adsorption onto lamellar materials, ion exchange and ceramic membrane techniques [1-3]. Due to its high toxicity and the epidemiological evidence of arsenic carcinogenicity $[4,5]$, drinking water regulations only permit the presence of extremely low concentrations of As (V). Both the European Community and the United States specify the current maximum concentration limit for arsenic in water intended for human consumption, to 10 ppb [6,7]. Successful removal of arsenic ions from aqueous solutions using nonspecific and specific solid adsorbents has been fully demonstrated, such as silica, zeolites and 
organofunctionalized and pillared clays [8-11].

The aim of the present investigation reports the performance of a natural smectite in unmodified and chemically modified forms in arsenic (V) adsorption process. The modified matrix was obtained through chemical modification was developed with organofunctionalization with 3-chloropropyltriethoxysilane and 2-mercaptopyrimidine. The natural and modified smectite samples were characterized by SEM, ${ }^{29} \mathrm{Si}-\mathrm{MAS} / \mathrm{NMR}$, FTIR, textural and $\mathrm{CHN}$ analysis. These matrices were used for arsenic (V) adsorption under batch process with As (V) concentration as variable at $\mathrm{pH} 2.0$ and temperature at $298 \pm 1 \mathrm{~K}$. The kinetic parameters were analyzed by the Lagergren and Elovich models gave a good fit for a pseudo-second order reaction for all systems. The energetic effect caused by arsenic/reactive centers on smectite interaction at the solid/liquid interface was determined through calorimetric titration procedure.

\section{EXPERIMENTAL}

\section{Raw material and chemical modification}

The sampled clay from southeast region of Minas Gerais, Brazil, with particle size less than $2 \mu \mathrm{m}$, was separated by sedimentation. The cation-exchange capacity (CEC) was measured in order to evaluate its potential use for intercalation and also organofunctionalization. The exchange property was determined by the ammonium acetate methodology [2], using a concentration of $2.0 \mathrm{~mol} \mathrm{dm}{ }^{-3}$ ammonium acetate at $\mathrm{pH} 8.0$, to give $1.28 \mathrm{mmol} \mathrm{g}^{-1}$ on an air-dried basis.

The first stage in the preparation of functionalization of natural smectite (S) by homogeneous method is the synthesis with silylating agent. One portion of about $10 \mathrm{~g}$ of natural smectite was suspended in $25.0 \mathrm{~cm}^{3}$ of 3-chloropropyltriethoxysilane under a nitrogen purge at 298 $\pm 1 \mathrm{~K}$ for $1 \mathrm{~h}$. The solid was named $\mathrm{S}_{3 \mathrm{CPS}}$. In the second stage, the total mass obtained in first stage of $\mathrm{S}_{3 \mathrm{CPS}}$ was suspended in $3.0 \mathrm{~cm}^{3}$ of 2-mercaptopyrimidine was added under flowing nitrogen to the suspension and stirred for $1 \mathrm{~h}$, followed by more $72 \mathrm{~h}$ at $363 \pm 1 \mathrm{~K}$. The resulting material was named $\mathrm{S}_{\mathrm{MPY}}$.

\section{Characterization}

The nuclear magnetic resonance spectra were recorded with a Bruker AC300/P solid state high-resolution spectrometer, by using cross-polarization and magic angle spinning (CP-MAS). The frequency was $75.5 \mathrm{MHz}$, with rotational frequency of $26 \mathrm{MHz}$ and acquisition time of $0.8 \mathrm{~s}$

The samples for scanning electron microscopy (SEM) images were recorded on a Leo-Zeiss $430 \mathrm{Vp}$ at LNLS, Brazil, in conditions of analysis using secondary images at $20 \mathrm{kV}$, with a working distance of $11 \mathrm{~mm}$.

The surface and porosity analyses were carried out with a volumetric adsorption analyzer Micromeritics ASAP 2010 at $77 \mathrm{~K}$. The samples were pre-treated at $373 \pm 1 \mathrm{~K}$ for $24 \mathrm{~h}$. After that, the samples were submitted to $298 \pm 1 \mathrm{~K}$ under vacuum, reaching the residual pressure of $10^{-4} \mathrm{~Pa}$. For area and pore calculations the Brunauer-Emmett-Teller (BET) and Barret-Joyner-Halenda (BJH) methods were evaluated.

The carbon, nitrogen and hydrogen contents were determined on a Perkin-Elmer 2400 Series II microelemental analyzer, and at least two independent determinations were performed for each sample.

The sample for infrared spectroscopy was oven-dried at $393 \pm 1 \mathrm{~K}$ to remove adsorbed water. The sample of about $1.3 \mathrm{mg}$ was finely ground for $1 \mathrm{~min}$, combined with 100.0 $\mathrm{mg}$ of oven-dried spectroscopic grade $\mathrm{KBr}$ and pressed with 7.0 ton into a disc under vacuum. The spectrum of the sample was recorded in the 400 to $4000 \mathrm{~cm}^{-1}$ range by accumulating 65 scans at $4 \mathrm{~cm}^{-1}$ of resolution, using a Perkin-Elmer 1760X Fourier transform infrared instrument.

\section{Adsorption}

Adsorption isotherms were obtained using the batchwise method by suspending a series of samples of $20.0 \mathrm{mg}$ of the each matrix ( $\mathrm{S}$ and $\mathrm{S}_{\mathrm{MPY}}$ ) with $20.0 \mathrm{~cm}^{3}$ aqueous solution of arsenic (V) cation at concentration varying from 1.0 to $2.5 \mathrm{mmol} \mathrm{dm}^{-3}$, mechanically stirred at $298 \pm 1 \mathrm{~K}$. Based on the time required to reach equilibrium, which was previously established as near $18 \mathrm{~h}$, then $24 \mathrm{~h}$ was chosen to ensure maximum adsorption. The amount of the arsenic (V) cation removed during adsorption $\left(\mathrm{mmol} \mathrm{dm}^{-3}\right)$ was calculated by the expression $\mathrm{N}_{\mathrm{f}}=\left(\mathrm{n}_{\mathrm{i}}-\mathrm{n}_{\mathrm{S}}\right) / \mathrm{m}$, were $\mathrm{N}_{\mathrm{f}}$ is the number of moles of arsenic adsorbed on the pendant reactive groups of the synthetic phyllosilicate samples, $n_{i}$ and $\mathrm{n}_{\mathrm{S}}$ are the number of moles in the initial solution and in the supernatant after equilibrium, respectively, and $\mathrm{m}$ is the mass of samples used for each phyllosilicate sample [12] The supernatant concentrations were determined by ICPOES Varian Liberty apparatus. In every case, all samples were analyzed in triplicate.

\section{RESULTS}

\section{Characterization of materials}

The SEM images of natural $\mathrm{S}$ and modified $\mathrm{S}_{\mathrm{MPY}}$ smectite samples are shown in Figs. 1a and 1b. In Fig. 1a, particles formed by large agglomerates of irregular shapes are observed. There is strong tendency towards aggregation and the material has compact aspect. Fig. 1b displays the SEM micrographs of the organofunctionalized smectite. In this case, the particles are apparently smaller in size and are constituted of disordered, thin sheet particle aggregates. One can conclude that functionalization promotes the formation of disordered and less cohesive aggregates, probably due to reduction of the edge-to-edge and face-to-face interactions. Unlike the hydrophilic unmodified smectite sample, which formed large size aggregates after drying, the functionalized samples were hardly dispersed in water (hydrophobic) and 

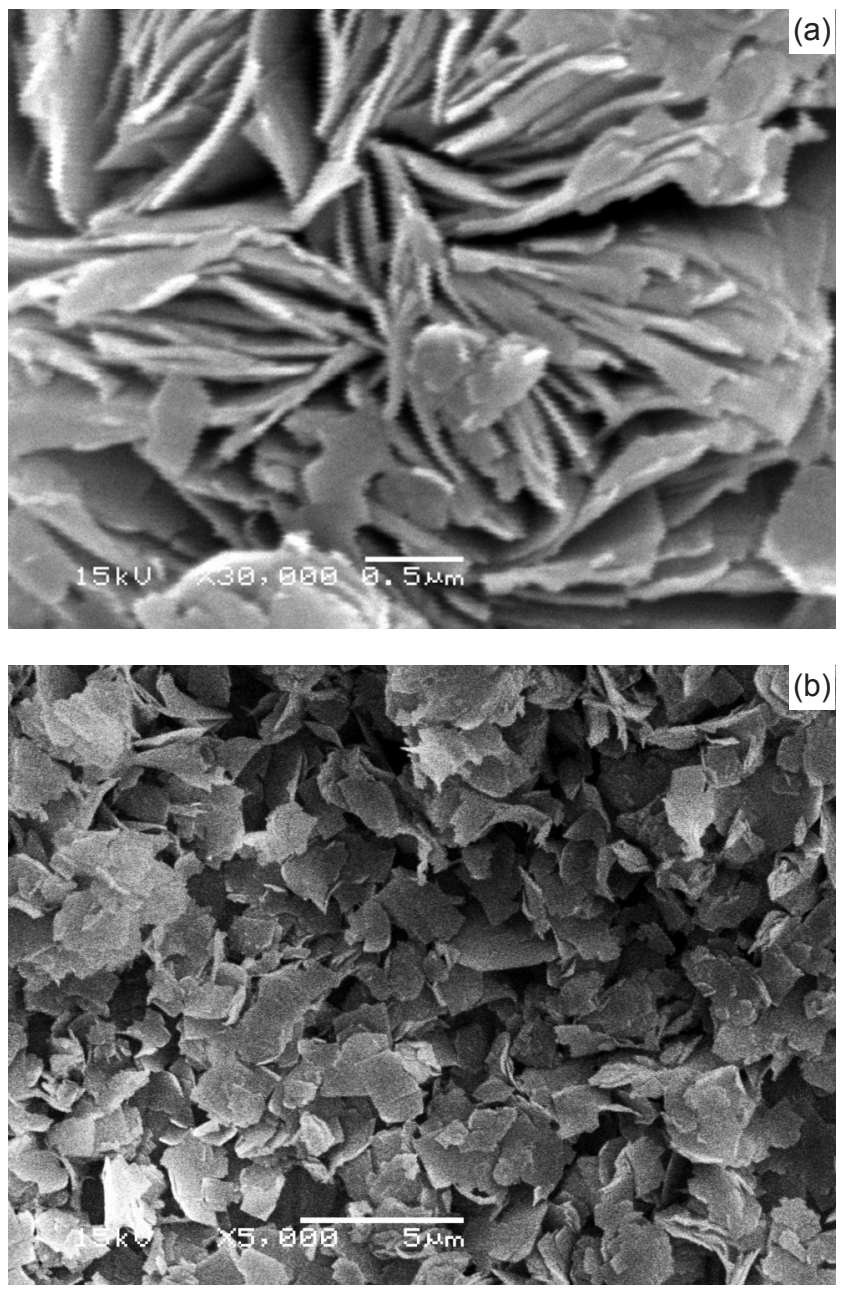

Figure 1: SEM micrographs of natural and modified smectite: S (a) and $\mathrm{S}_{\mathrm{MPY}}(\mathrm{b})$.

[Figura 1: Micrografias MEV das amostras natural e modificada de esmectita $S($ a $)$ e $S_{M P Y}(b)$.]

easily kept as a powder after drying. This change constitutes an important advantage considering industrial application.

The infrared spectrum is a useful technique to confirm, even qualitatively, the presence of the organic molecules inserted into the lamellar cavity of the inorganic matrix; infrared spectroscopy can provide detailed information about water structure in interlayer spaces (Fig. 2). The main features of the $\mathrm{S}_{\mathrm{MPY}}$ spectrum include a large broad band between 3400 and $3200 \mathrm{~cm}^{-1}$, which is attributed to $\mathrm{O}-\mathrm{H}$ stretching of the surface; silanol groups were observed at 900 $\mathrm{cm}^{-1}$. The adsorption band at $1600 \mathrm{~cm}^{-1}$ is due to deformation vibrations of absorbed water molecules $[11,12]$. The $\mathrm{S}_{\mathrm{MPY}}$ system showed characteristic bands for aliphatic C-H stretching vibrations due to pendant alkyl chains at around 2900- $2750 \mathrm{~cm}^{-1}, 1600,1450$ and $1250 \mathrm{~cm}^{-1}$ due to $\mathrm{C}=\mathrm{N}$ and $\mathrm{C}=\mathrm{C}$ stretching vibrations of attached silanol groups from intercalation process.

Specific surface area is a significant parameter affecting the adsorptive capacity of an adsorbent. The uptake of anions increases with proportional increase of the adsorbent material. The results obtained for the surface area of natural

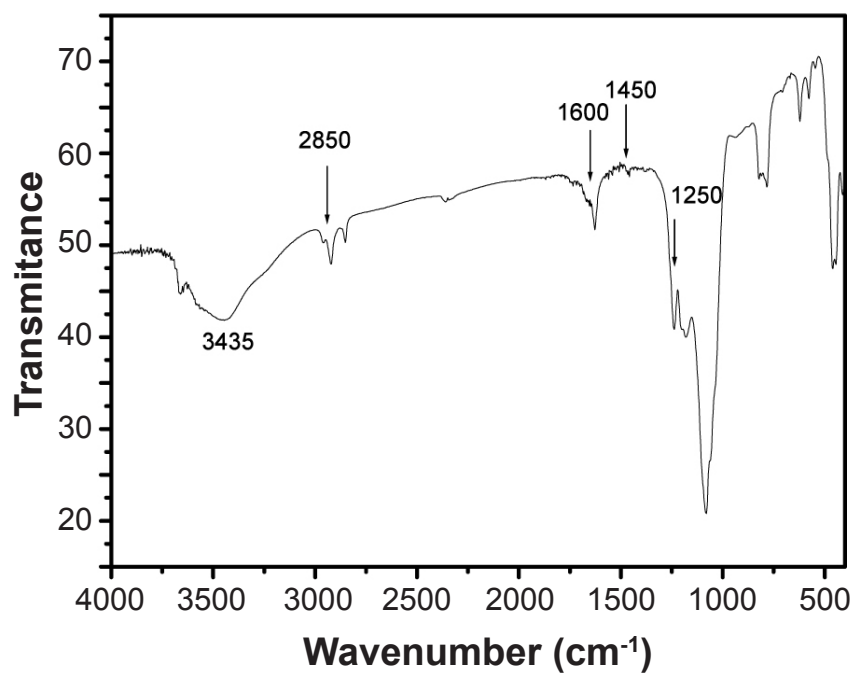

Figure 2: Infrared spectrum of modified Smectite sample $\left(\mathrm{S}_{\mathrm{MPY}}\right)$.

[Figura 2: Espectro de infravermelho da amostra de esmectita modificada $\left(S_{M P Y}\right)$.]
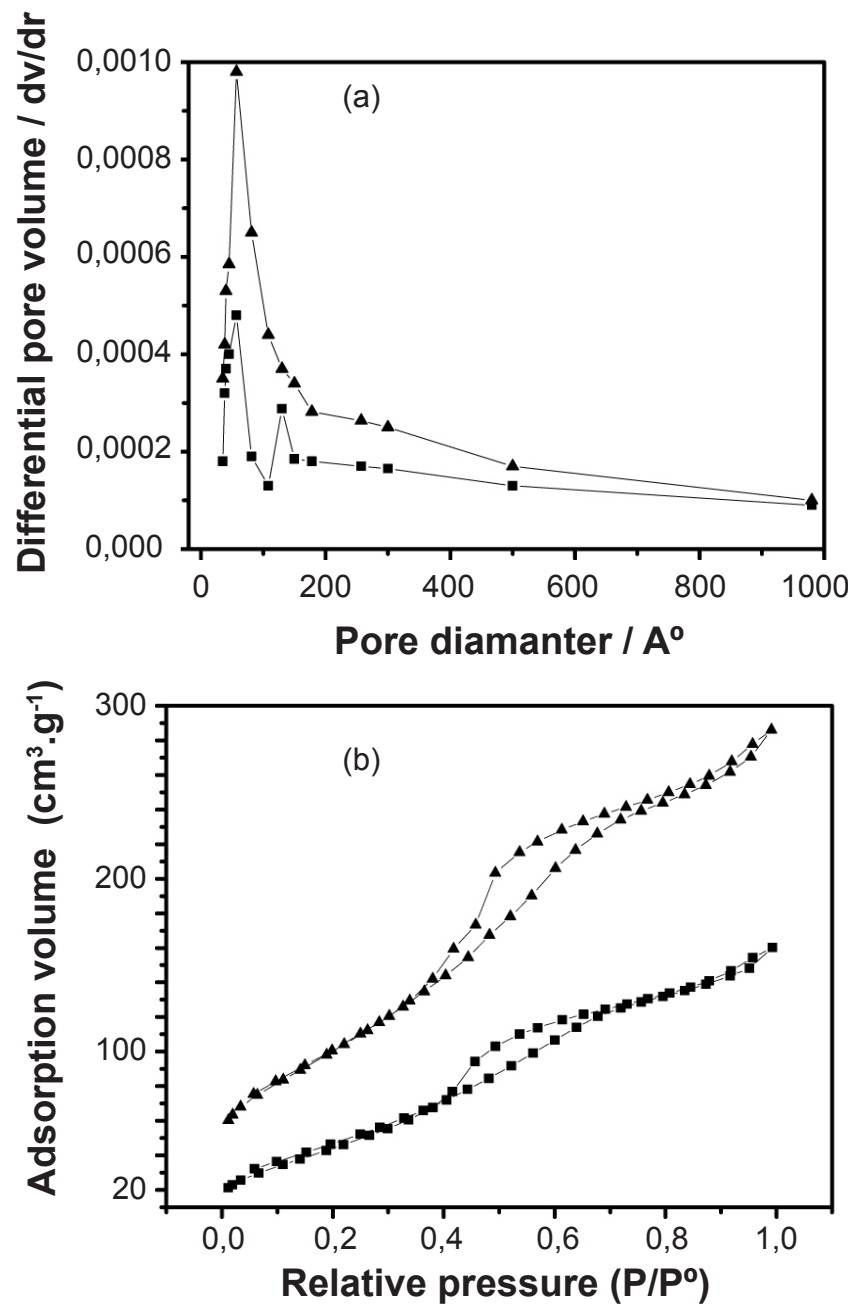

Figure 3: Pore distribution for natural and modified smectite (a) and nitrogen adsorption-desorption isotherm (b): $\mathrm{S}(\boldsymbol{\square})$, and $\mathrm{S}_{\mathrm{MPY}}(\mathbf{\Delta})$. [Figura 3: Distribuição de poros para a esmectita natural $e$ modificada (a) e isoterma de adsoção-desorção de nitrogênio (b): $S(\mathbf{\square})$, and $S_{M P Y}(\mathbf{\Delta})$.] 

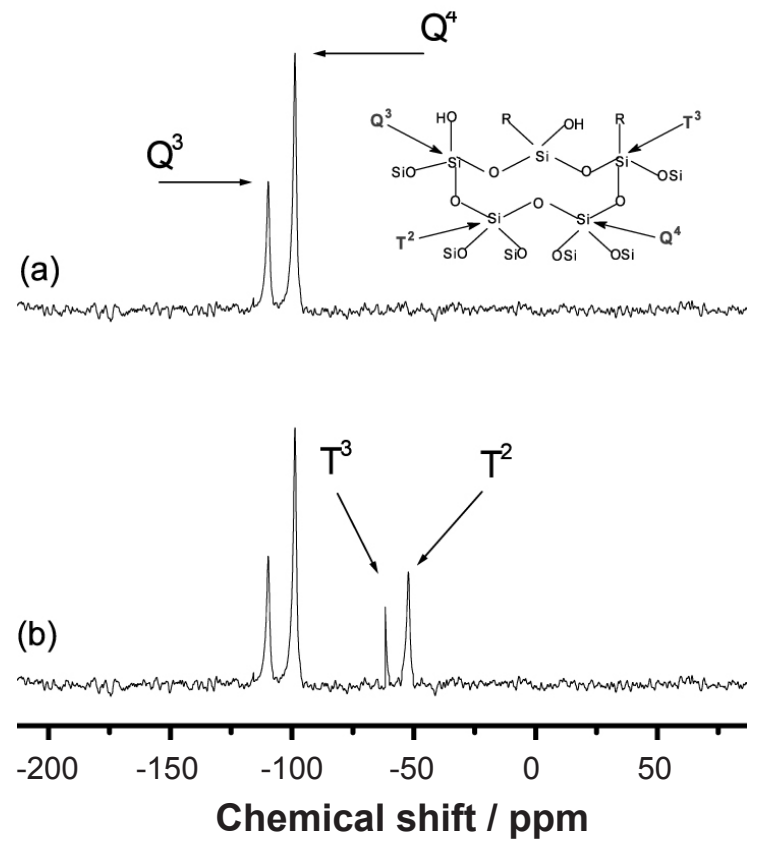

Figure 4: ${ }^{29} \mathrm{Si}$ MAS-NMR spectra of natural, S (a) and modified Smectite, $\mathrm{S}_{\mathrm{MPY}}(\mathrm{b})$.

[Figura 4: Espectros de ${ }^{29}$ Si MAS-NMR da natural, $S($ a) e smectite modificada, $S_{M P Y}(b)$.]

and modified smectite samples $\left(\mathrm{S}_{\mathrm{MPY}}\right)$ by the BET method were $25.1 \pm 0.1$ and $216.9 \pm 0.1 \mathrm{~m}^{2} \mathrm{~g}^{-1}$, respectively. The modified smectite sample presented a unimodal distribution of pore sizes while $\mathrm{S}$ showed a bimodal distribution (Fig. 3a). The adsorption-desorption isotherms of gaseous nitrogen on natural and modified smectite fitted the type IV curve behavior, as illustrated in Fig. 3b, indicating that the pores are formed by open cylinders on the two extremes [13]. Through the BJH method the pore diameters obtained for unmodified and modified smectite were $26.0 \pm 1$ and $79.0 \pm$ $1 \mathrm{~nm}$, respectively. However, the pore distribution was not homogeneous.

Important features related to the information about the intercalation and immobilization of pedant group on the inorganic structure of the hybrid formed can be obtained through ${ }^{29} \mathrm{Si}$ MAS-NMR spectra in the solid state. Silicon nuclei were then examined in order to better characterize the natural and synthetic compounds. The ${ }^{29} \mathrm{Si}$ MAS-NMR spectra in the solid state for both materials $\left(\mathrm{S}\right.$ and $\mathrm{S}_{\mathrm{MPY}}$ ) confirm the covalent bond formed between the silylating agents and the silanol groups dispersed on the $\mathrm{S}$ surface (Fig. 4). Natural smectite (S) shows two main peaks at -110 and $-105 \mathrm{ppm}$ and these are assigned to $\mathrm{Q}^{3}\left[(\mathrm{SiO})_{3} \mathrm{SiOH}\right]$ and $\mathrm{Q}^{4}[(\mathrm{SiOH}) 4 \mathrm{Si}]$ framework silanol site. $\mathrm{Q}^{4}$ is clearly the dominant peak in both spectra because it is the most abundant sites. In the functionalized smectite two peaks appeared at -52 and $-60 \mathrm{ppm}$, which are assigned to $\mathrm{T}^{2}\left[(\mathrm{SiO})_{2} \mathrm{SiOH}-\mathrm{R}\right]$ and $\mathrm{T}^{3}\left[(\mathrm{SiO})_{3} \mathrm{Si}-\mathrm{R}\right]$ sites, respectively [14].

The amount incorporated was calculated based on the amount of hydrogen, nitrogen and carbon existent in the modified smectite sample. Based on the analytical data for both hybrid phyllosilicate, the density of these pendant organic molecules immobilized on the smectite layer of the inorganic matrix can be calculated. Thus, the sililant agents grafted onto smectite structure gave an amount of $6.57 \pm$ $0.21 \mathrm{mmol} \mathrm{g}^{-1}$.

\section{Adsorption study}

The original and modified matrices adsorption capacities for the arsenic halide by modified smectite samples depend on the nature of the complex formed on the surface and also on the affinity of arsenic (V) cation for the particular attached ligand [14, 15] and on the number of reactive groups anchored in the structure inorganic matrix. The maximum adsorption capacities obtained experimentally, $\mathrm{N}_{\mathrm{f}}^{\text {max }}$, for arsenic $(\mathrm{V})$ halide on $\mathrm{S}$ and $\mathrm{S}_{\mathrm{MPY}}$ are listed in Table I. $\mathrm{N}_{\mathrm{f}}{ }^{\max }$ is highest for arsenic $(\mathrm{V})$ on the natural and modified matrices.

The interaction of this cation with bridging immobilized external and internal surfaces of the synthetic phyllosilicate structure is governed by the microenvironment round such arrangements, which is usually composed of basic and acidic reactive centers, mainly in the internal structure of hydration. Hydroxyl groups act as bridges that result from inorganic matrices intercalation and organofunctionalization process.

The capacity of these materials to remove arsenic from water was followed by isotherms of adsorption process. For this adsorption process the modified Langmuir can be applied, equation A [15]:

$$
\mathrm{Nf}=\frac{\mathrm{K}_{\mathrm{L}} \mathrm{bC}_{\mathrm{s}}}{1+\mathrm{bC}_{\mathrm{s}}}
$$

Table I - Kinetics for pseudo-first and pseudo-second order Lagergren and Elovich models calculated for arsenic (V) adsorption onto natural and modified smectite.

[Tabela I - Modelos cinéticos de pseudo-primeira e pseudo-segunda ordem de Lagergren e Elovich calculados para adsorção de arsênio (V) em natural e modificada esmectita.]

\begin{tabular}{|c|c|c|c|c|c|c|c|c|c|}
\hline \multirow[b]{2}{*}{ Sample } & \multicolumn{3}{|c|}{ Pseudo-first order } & \multicolumn{3}{|c|}{ Pseudo-second order } & \multicolumn{3}{|c|}{ Elovich } \\
\hline & $\begin{array}{l}\mathrm{k}_{1} \times 10^{2} \\
\left(\mathrm{~min}^{-1}\right)\end{array}$ & $\begin{array}{c}\mathbf{N}_{\text {fcal }} \\
\left(\mathrm{mmol} \mathrm{g}^{-1}\right)\end{array}$ & $\mathrm{r}^{2}$ & $\begin{array}{c}\mathrm{k}_{2} \times 10^{3} \\
\left(\mathrm{mmolg}^{-1} \mathrm{~min}^{-1}\right)\end{array}$ & $\begin{array}{c}\mathbf{N}_{\text {fcal }} \\
\left(\mathrm{mmol} \mathrm{g}^{-1}\right)\end{array}$ & $\mathrm{r}^{2}$ & $\begin{array}{c}\propto \times 10^{3} \\
\mathrm{~g} \mathrm{mmol}^{-1} \mathrm{mim}^{2}\end{array}$ & $\begin{array}{c}\beta \\
\mathrm{mmol} \mathrm{g}^{-1} \mathrm{mim}^{-1}\end{array}$ & $r^{2}$ \\
\hline$S$ & $1.2 \pm 0.1$ & $4.8 \pm 0.2$ & 0.998 & $4.9 \pm 0.2$ & $6.3 \pm 0.4$ & 0.999 & $5,3 \pm 0.2$ & $1.2 \pm 0.1$ & 0.999 \\
\hline $\mathrm{S}_{\mathrm{MPY}}$ & $2.1 \pm 0.5$ & $10.2 \pm 0.4$ & 0.989 & $14.0 \pm 0.2$ & $11.0 \pm 0.2$ & 0.999 & $25.5 \pm 0.3$ & $2.7 \pm 0.1$ & 0.999 \\
\hline
\end{tabular}


where $\mathrm{C}_{\mathrm{s}}$ is the final number of moles in the supernatant in each point of the titration, $\mathrm{N}_{\mathrm{f}}$ is the number of moles of arsenic cation adsorbed per gram of the smectite in each adsorption obtained batch procedure. The plateau of the isotherm enables $K_{L}$ determination that reflected the affinity of the adsorbate on the surface. The $\mathrm{b}$ or $\mathrm{N}_{\mathrm{s}}$ value is the upper limit and represents the maximum adsorption, determined by the number of reactive surface reactive sites [16-17].

The coefficient of determination values $\left(\mathrm{r}^{2}\right)$ were used in order to find the degrees of fit of the isotherm adsorption and kinetic models with the experimental data [18], as defined by equation $\mathrm{B}$ :

$$
\mathrm{r}^{2}=\frac{\sum\left(\mathrm{N}_{\mathrm{fCAL}}-\overline{\mathrm{N}}_{\mathrm{fEXP}}\right)^{2}}{\sum\left(\mathrm{N}_{\mathrm{fCAL}}-\overline{\mathrm{N}}_{\mathrm{fEXP}}\right)^{2}+\sum\left(\mathrm{N}_{\mathrm{fCAL}}-\mathrm{N}_{\mathrm{fEXP}}\right)^{2}}
$$

where $\mathrm{N}_{\mathrm{fEXP}}\left(\mathrm{mmol} \mathrm{g}^{-1}\right)$ is the experimental amount of cations exchanged by the natural and the modified smectite samples and $\mathrm{N}_{\mathrm{fCAL}}$ is the amount of cations obtained by isotherm models.

The available reactive atoms from the organic molecules, the maximum adsorption values are listed in Table I and shown in Fig. 5, suggested that only one cation can saturate these basic reactive centers introduced in smectite structure.

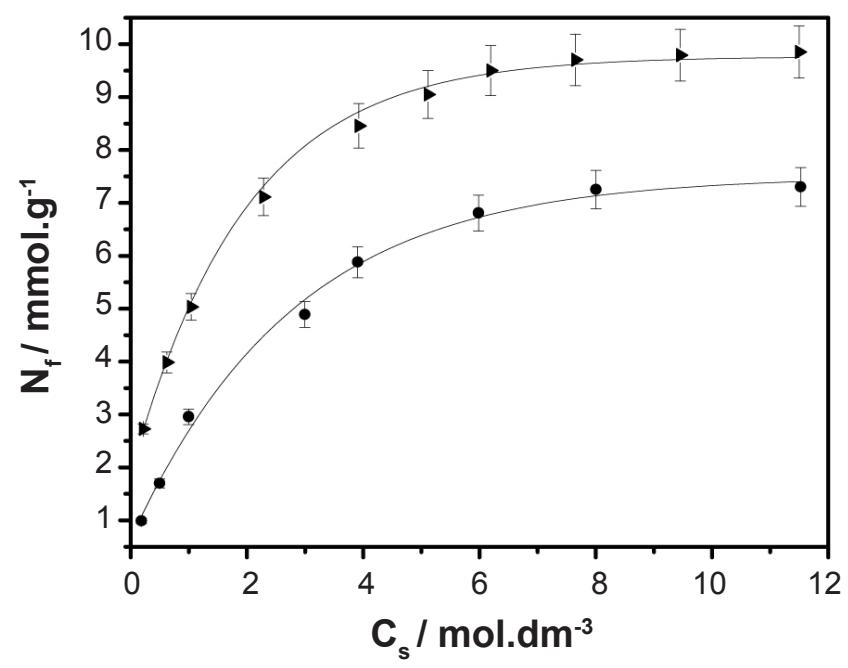

Figure 5: Adsorption performance of natural $(\mathrm{S})(\bullet)$ and modified $\left(\mathrm{S}_{\mathrm{MPY}}\right)(\triangleright)$ smectite samples in aqueous medium of As (V).

[Figura 5: Desempenho de adsorção das amostras de esmectita natural $(S)(\bullet)$ e modificada $\left(S_{M P Y}\right)(\triangleright)$ em meio aquoso de As $(V)$.]

\section{Kinetic of adsorption}

Pseudo-first order kinetics using the Lagergren equation [19] is generally expressed by equation C,

$$
\frac{\partial \mathrm{N}_{\mathrm{t}}}{\partial \mathrm{t}}=\mathrm{k}_{1}\left(\mathrm{~N}_{\mathrm{fEQ}}-\mathrm{N}_{\mathrm{f}}\right)
$$

After integration and applying the boundary conditions, $\mathrm{N}_{\mathrm{t}}=0$ for $\mathrm{t}=0$ and $\mathrm{N}_{\mathrm{t}}=\mathrm{N}_{\mathrm{t}}$ at $\mathrm{t}=\mathrm{t}$, the integrated form of equation $\mathrm{C}$ becomes:

$$
\ln \left(\mathrm{N}_{\mathrm{fEQ}}-\mathrm{N}_{\mathrm{f}}\right)=\ln \mathrm{N}_{\mathrm{fEQ}}-\mathrm{k}_{\mathrm{l}} \mathrm{t}
$$

where $\mathrm{N}_{\mathrm{fEQ}}$ and $\mathrm{N}_{\mathrm{f}}\left(\mathrm{mmol} . \mathrm{g}^{-1}\right)$ are the amounts of arsenic adsorbed at equilibrium and at a given time $\mathrm{t}(\mathrm{min})$, respectively, and $\mathrm{k}_{1}$ is the rate constant for pseudo-first order adsorption $\left(\mathrm{min}^{-1}\right)$.

When the rate of reaction of an adsorption reaction is controlled by chemical exchange, then a pseudo-second order model can be better adjusted to the experimental kinetic data [20], as expressed by equation $\mathrm{E}$.

$$
\frac{\partial \mathrm{N}_{\mathrm{f}}}{\partial \mathrm{t}}=\mathrm{k}_{2}\left(\mathrm{~N}_{\mathrm{fEQ}}-\mathrm{N}_{\mathrm{f}}\right)^{2}
$$

After integration and applying the boundary conditions, $\mathrm{N}_{\mathrm{t}}=0$ for $\mathrm{t}=0$ and $\mathrm{N}_{\mathrm{t}}=\mathrm{N}_{\mathrm{t}}$ at $\mathrm{t}=\mathrm{t}$, the integrated form of equation $\mathrm{F}$ becomes :

$$
\frac{\mathrm{t}}{\mathrm{N}_{\mathrm{f}}}=\left(\frac{1}{\mathrm{k}_{2} \mathrm{~N}_{\mathrm{fEQ}}^{2}}\right)+\left(\frac{1}{\mathrm{~N}_{\mathrm{fEQ}}}\right) \mathrm{t}
$$

where $\mathrm{k}_{2}$ is the pseudo-second order rate $\left(\mathrm{mmol}^{-1} \mathrm{~min}^{-1}\right)$. The values of $k_{2}$ can be obtained from the slope of the nonlinear plot of $\mathrm{N}_{\mathrm{f}}$ versus t. Carrying out a set of experiments at constant temperature and monitoring the amount adsorbed with time, the kinetics of the adsorption process should be known.

Carrying out a set of experiments at constant temperature and monitoring the amount adsorbed with time, the kinetics of the adsorption process should be known. The adsorption using the Lagergren model can also be explored [20], as proposed in equation $\mathrm{C}$.

The useful Elovich equation for energetically heterogeneous solid surfaces is represented by equation $\mathrm{G}$ $[19,20]$ :

$$
\mathrm{Nf}=\ln (\alpha \beta \mathrm{t})^{\beta}
$$

where $\alpha$ and $\beta$, the Elovich coefficients, represent the initial adsorption rate $\left(\mathrm{mmolg}^{-1} \mathrm{~min}^{-1}\right)$ and the desorption coefficient (g.mmol ${ }^{-1}$ ), respectively.

Adsorptionincreased relativity rapidly up to $1 \mathrm{~h}$ and slowly increased as equilibrium was reached, as shown in Fig. 6. The arsenic $(\mathrm{V})$ cation uptake became almost constant after 200 min for $\mathrm{S}$ and after 150 min for $\mathrm{S}_{\mathrm{MPY}}$ samples, which can be considered reaching the equilibrium condition. The initial high rate of adsorption can be attributed to the existence the exposed reactive basic centers for interaction on the readily accessible surfaces. However, as the coverage increased, the number of available surface sites for adsorption decreases until it reaches equilibrium, when the uptake is controlled by the rate at which the adsorbate is transported from the exterior to the interior sites of the adsorbent particles.

Second order kinetic plots presented better linearity with $\mathrm{r}^{2}>0.99$ and the second order rate constant, $\mathrm{k}_{2}$, varied from 


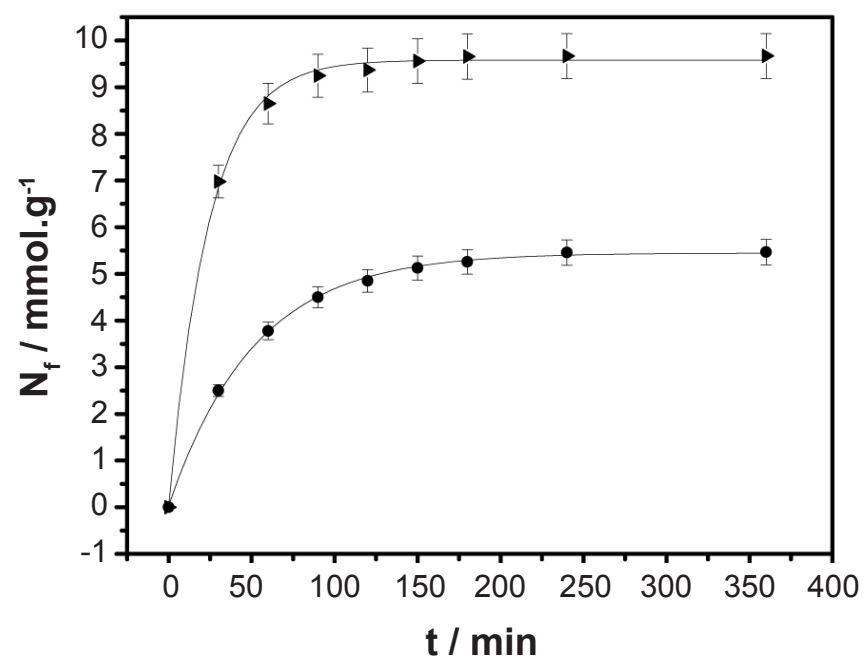

Figure 6: Isotherm of time of natural $(\mathrm{S})(\bullet)$ and modified $\left(\mathrm{S}_{\mathrm{MPY}}\right)$ ( ) smectite samples in aqueous medium of $\mathrm{As}(\mathrm{V})$.

[Figura 6: Isotermas de tempo da amostra de esmectita natural $S$ $(\bullet)$ e modificada (SMPY) (\) em meio aquoso de As $(V)$.]

4.8 to $14.0 \mathrm{~g} \mathrm{mg}^{-1} \mathrm{~min}^{-1}$, as listed in Table I. Second order kinetics suggests that the number of adsorption sites on the natural and modified phyllosilicate surfaces and the number of arsenic cation in the liquid phase together determine the kinetics. Depending on $\mathrm{pH}$, different cations species may be held to the inorganic matrix surface at appropriate ionexchange sites.

\section{Thermodynamic of adsorption}

Thermostated solutions of the cations were incrementally added to the calorimetric vessel and the thermal effect of the titration $\mathrm{Q}_{\mathrm{t}}(\mathrm{J})$ was determined. Under the same experimental conditions, the corresponding thermal effect of the dilution of the cationic solution was obtained in the absence of the support $Q_{d}(J)$. The thermal effect of the hydration of the matrices in water was determined as before [21,22]. Under such conditions, the net thermal effect of adsorption $\Sigma Q_{r}(J)$ was obtained through equation $\mathrm{H}$.

$$
\Sigma \mathrm{Q}_{\mathrm{r}}=\Sigma \mathrm{Q}_{\mathrm{tit}}-\Sigma \mathrm{Q}_{\mathrm{dil}}-\Sigma \mathrm{Q}_{\mathrm{sol}}
$$

The calorimetric results are presented in Fig. 7 and Table II. The change in enthalpy associated with arsenic cation / natural or modified smectite $\left(\Sigma \Delta_{\mathrm{int}} \mathrm{h}\right)$ adsorption can be determined by the modified Langmuir, equation I:

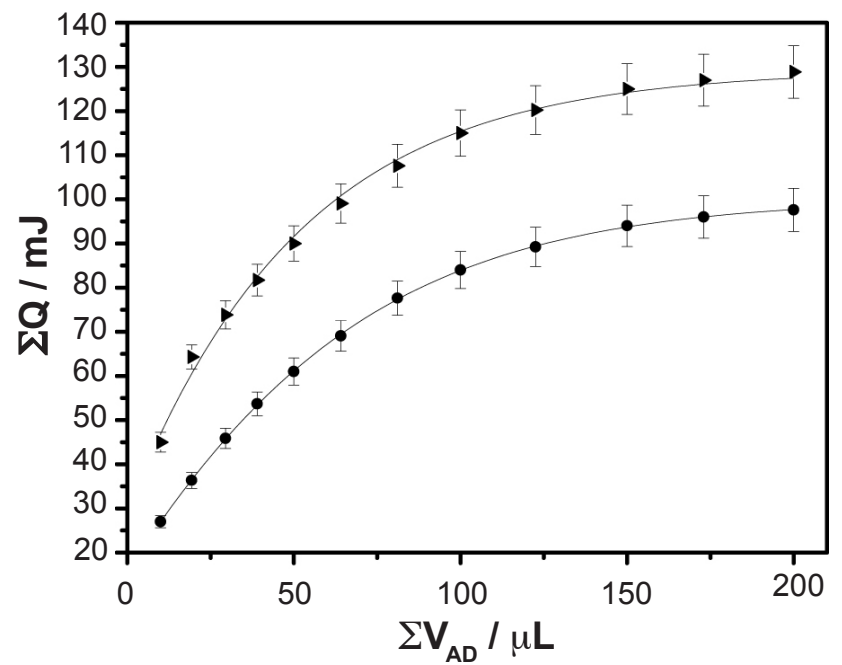

Figure 7: The resulting thermal effects of the adsorption isotherms of the arsenic cation: $\mathrm{S}(\bullet)$ and $\mathrm{S}_{\mathrm{MPY}}($ ).

[Figura 7: Efeitos térmicos resultantes das isotermas de adsorção de cation arsênio: $S(\bullet)$ e $S_{M P Y}($ ).]

$$
\mathrm{X} / \Delta_{\mathrm{r}} \mathrm{h}=1 /\left(\mathrm{K}_{\mathrm{L}}-1\right) \Delta_{\text {int }} \mathrm{h}+\mathrm{X} / \Delta_{\text {int }} \mathrm{h}
$$

where $\mathrm{X}$ is the molar arsenic cation fractions remaining in solution, $\Delta_{\mathrm{r}} \mathrm{h}$ is the enthalpy obtained from the quotient between the sums of the resulting effect per mass smectite samples $\left(\Sigma \mathrm{Q}_{\mathrm{r}} \mathrm{h} / \mathrm{m}\right), \Delta_{\mathrm{int}} \mathrm{h}$ is the enthalpy for monolayer formation and $\mathrm{K}_{\mathrm{L}}$ a parameter associated with the equilibrium constant. $\Delta_{\text {int }} \mathrm{h}$ and $\mathrm{K}_{\mathrm{s}}$ values can be determined from coefficients after non-linear regression of the experimental isotherms. The molar enthalpy of interaction process [23] can be calculated through the equation $\mathrm{J}$.

$$
\Delta_{\text {int }} \mathrm{H}=\Delta_{\text {int }} \mathrm{h} / \mathrm{N}_{\mathrm{s}}
$$

where $\mathrm{N}_{\mathrm{s}}$ is the number of adsorbent moles after reaching calorimetric equilibrium. From $\mathrm{K}_{\mathrm{L}}$ values the Gibbs energy $[23,24]$ is calculated by equation $\mathrm{K}$ :

$$
\Delta_{\text {int }} \mathrm{G}=-\mathrm{RT} \ln \mathrm{K}_{\mathrm{L}}
$$

where $K_{L}$ is the equilibrium constant obtained from the Langmuir model, $\mathrm{T}$ is the absolute temperature and $\mathrm{R}$ is the

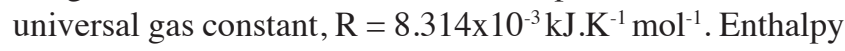
values $[23,24]$ are obtained by considering equation $\mathrm{L}$ :

$$
\Delta_{\text {int }} \mathrm{G}=\Delta_{\text {int }} \mathrm{H}-\mathrm{T} \Delta_{\text {int }} \mathrm{S}
$$

Table II - Thermodynamic data for arsenic (V) adsorption into natural and modified smectite.

[Tabela II - Dados termodinâmicos para adsorção de arsênio (V) em natural e modificada esmectita.]

\begin{tabular}{cccccccc}
\hline Sample & $\begin{array}{c}\mathrm{N}_{\mathrm{s}} \\
\left(\mathrm{mmol} \mathrm{g}^{-1}\right)\end{array}$ & $\begin{array}{c}\mathrm{N}_{\mathrm{f}}^{\max } \\
\left(\mathrm{mmol} \mathrm{g}^{-1}\right)\end{array}$ & $\begin{array}{c}\Delta_{\text {int }} \mathrm{h} \\
\left(\mathrm{Jg}^{-1}\right)\end{array}$ & $\begin{array}{c}-\Delta_{\text {int }} \mathrm{H} \\
\left(\mathrm{kJmol}^{-1}\right)\end{array}$ & $\mathrm{K}_{\mathrm{L}} \times 10^{-3}$ & $\begin{array}{c}-\Delta_{\text {int }} \mathrm{G} \\
\left(\mathrm{kJmol}^{-1}\right)\end{array}$ & $\begin{array}{c}\Delta_{\text {int }} \mathrm{S} \\
\left(\mathrm{JK}^{-1} \mathrm{~mol}^{-1}\right)\end{array}$ \\
\hline $\mathrm{S}$ & $7.01 \pm 0.01$ & $5.45 \pm 0.12$ & $28.67 \pm 0.11$ & $4.09 \pm 0.02$ & $8.22 \pm 0.11$ & $22.34 \pm 0.11$ & $41.29 \pm 0.12$ \\
$\mathrm{~S}_{\mathrm{MPY}}$ & $12.15 \pm 0.07$ & $11.96 \pm 0.12$ & $70.35 \pm 0.15$ & $5.79 \pm 0.20$ & $17.39 \pm 0.11$ & $24.19 \pm 0.12$ & $61.80 \pm 0.10$ \\
\hline
\end{tabular}


The resulting thermal effects due to the interaction of arsenic(V) with modified and natural phyllosilicate samples are obtained by considering the deduction of dilution effect in water from the total thermal effect, applying equation $\mathrm{H}$.

Fig. 8 shows, as an example, one of the titration thermograms obtained when $\mathrm{S}$ adsorbs the arsenic cation: it shows that, under the conditions applied, equilibrium is attained rapidly. The integrated heat value is obtained by use of the data treatment Digitam 4.1 program (Thermometric).

The thermodynamic cycles for this series of intercalations involving a suspension (susp) of smectite matrices $\left(\mathrm{S}_{\mathrm{x}}\right)$ in solid state (Solid) and in aqueous solution (aq) with $\operatorname{arsenic}(\mathrm{V})$ cation (As) can be represented by the following calorimetric reactions (equations M-P):

$$
\begin{aligned}
& \mathrm{S}_{\mathrm{x}(\mathrm{aq})}+\mathrm{As}_{(\mathrm{aq})} \longrightarrow\left[\mathrm{S}_{\mathrm{x}} \ldots \mathrm{As}\right]_{(\text {(susp) }} \mathrm{Q}_{\mathrm{ti}} \\
& \mathrm{S}_{\mathrm{x} \text { (solid) }}+\mathrm{nH}_{2} \mathrm{O} \longrightarrow \mathrm{S}_{\mathrm{x}} \cdot \mathrm{nH}_{2} \mathrm{O}_{\text {(aq) }} \mathrm{Q}_{\text {sol }} \\
& \mathrm{As}_{(\mathrm{aq})}+\mathrm{nH}_{2} \mathrm{O} \longrightarrow \mathrm{As}_{\mathrm{nH}} \mathrm{O}_{(\mathrm{aq})} \mathrm{Q}_{\text {dil }} \\
& \mathrm{S}_{\mathrm{x}(\text { susp })}+[\mathrm{As}]_{(\mathrm{aq})} \longrightarrow\left[\mathrm{S}_{\mathrm{x}} \ldots \mathrm{As}\right]_{(\mathrm{sol})} \mathrm{Q}_{\mathrm{r}}
\end{aligned}
$$

The net thermal effect obtained for the calorimetric titration $\left(\Sigma \mathrm{Q}_{\mathrm{r}}=\Sigma \mathrm{Q}_{\mathrm{t}}-\Sigma \mathrm{Q}_{\mathrm{d}}-\sum \mathrm{Q}_{\mathrm{h}}\right)$, as given by equation $\mathrm{P}$, is experimentally represented as isotherms in Fig. 7. One example of application of regression non-linear involving arsenic cation adsorption is shown in Fig. 9. From equation I and the non-linear regression data for arsenic cation, the enthalpy $\left(\Delta_{\text {int }} \mathrm{H}\right)$ and entropy of interaction $\left(\Delta_{\text {int }} \mathrm{S}\right)$, can be obtained for all process, which enable calculation of molar enthalpy, equation I. The equilibrium constant the Gibbs free energy was calculated from equation $\mathrm{K}$ and combined with the enthalpic value, the entropy can also be calculated by equation $\mathrm{L}[22,23]$.

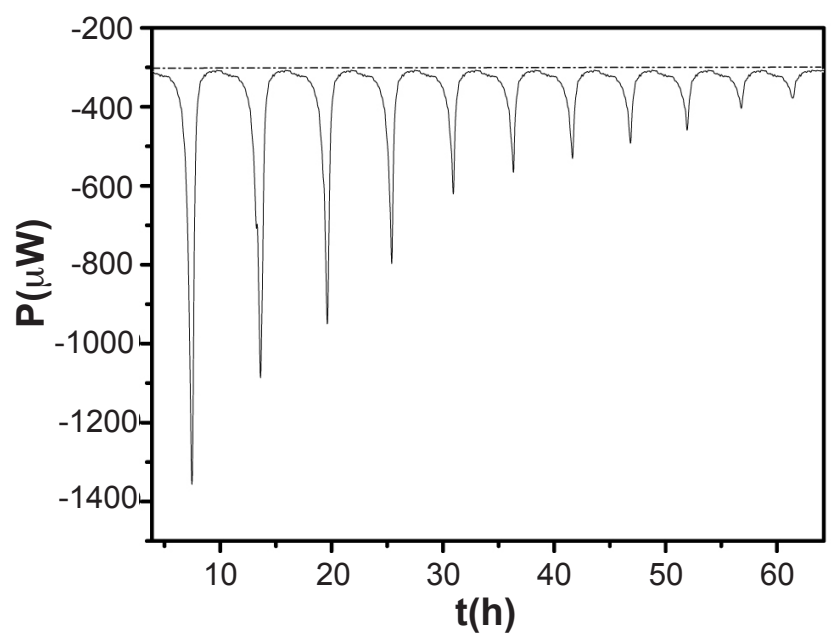

Figure 8: Variation of the thermal effect versus time upon microcalorimetric titration of natural smectite.

[Figura 8: Variação dos efeitos térmicos versus tempo por medidas calorimétricas da esmectita natural.]

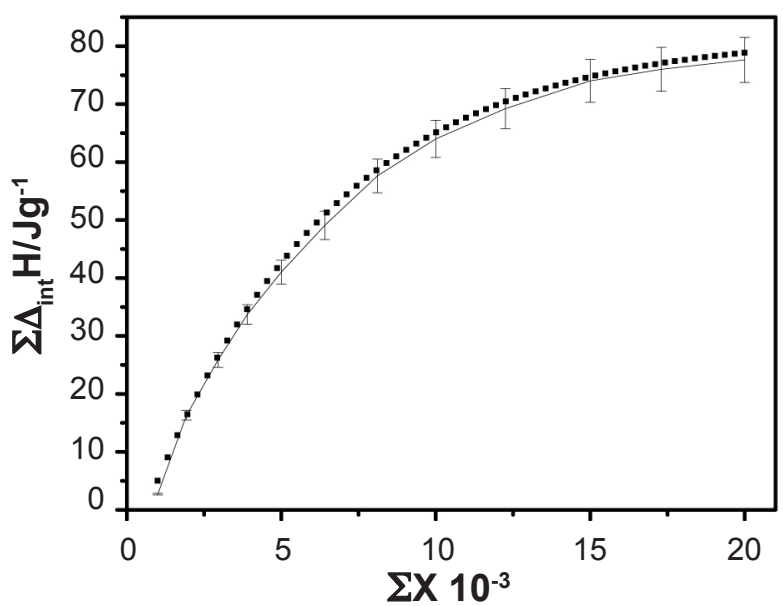

Figure 9: The resulting thermal effects of the adsorption isotherms of the arsenic cation. Experimental dada adjusted with regression non-linear: S (-) and non-linear adjust ( $\mathbf{\square})$.

[Figura 9: Efeitos térmicos resultantes de isotermas de adsorção do cation arsênio. Dados experimentais ajustados com regressão não linear: $S(-)$ e ajuste não linear.]

The Gibbs free energy, entropy and enthalpy values are listed in Table II. These values suggest that, during complex formation, desolvation disturbs the structure of reaction medium to promote the disorganization of system and, consequently, leads to increase in entropy. The thermodynamic values obtained with this study were in concordance with the values obtained by Evangelista et al. (2007) [24] with silica gel modified by 2-mercaptothiazoline adsorbing $\mathrm{Hg}$ (II) in aqueous medium. The spontaneity of this adsorption process is indicated by negative values of $\Delta_{\text {int }} \mathrm{G}$ and $\Delta_{\text {int }} \mathrm{H}$. The highest entropic values were observed for cation with the largest hydration volumes and illustrate the principle that the loss of water of hydration leads to a disorganization of the final systems [25-27]. In conclusion, all thermodynamic values are favorable, with exothermic enthalpy, negative Gibbs free energy, and positive entropy, and corroborate arsenic cation/unmodified and modified matrices adsorption at the solid/liquid interface.

\section{CONCLUSION}

The kinetics of adsorption of arsenic (V) cation used in this investigation on natural and modified smectite were complex, but it seems that this interactive effect is better expressed by a pseudo-second order process. Nonlinear regression methods were compared to evaluate the experimental data with a pseudo-second order kinetic model. Non-linear regression exhibited a higher coefficient of determination for the calculated isotherm. Considering all the above results, the kinetics of second order for cation adsorption on natural and modified smectite is better adjusted for arsenic (V). The quantitative interaction of arsenic cation/reactive centers on the smectite samples were followed calorimetrically at the solid/liquid interface to give favorable sets of thermodynamic data, such as exothermic enthalpy, negative Gibbs free energy, and positive entropic 
values.

\section{ACKNOWLEDGEMENTS}

The authors are indebted to CNPq for fellowships and financial support, and LNLS, Campinas, for the HRTEM measurements.

\section{REFERENCES}

[1] M. S. Rahaman, A. Busu, M. R. Islam, Bioresurse Technology 99 (2008) 2815.

[2] H. Guo, D. Stüben, Z. Berner, J. Colloid Interface Sci. 315 (2007) 47.

[3] M. P. Elizalde-Gonzáles, J. Mattusch, W. D. Einicke, R. Wennrich, Chem. Eng. J. 81 (2001) 187.

[4] A. E. Pagana, S.D. Sklari, E. S. Kikkinides, V.T.Zaspalis, Micropor. Mesopor. Mater. 110 (2008) 150.

[5] E. M. Vrijenhoek, J. J. Waypa, Desalination 130 (2000) 265.

[6] European Community, 1901. Directive related with drinking water quality intended for human consumption, Brussels, Belgium (1998).

[7] EPA Office of Ground Water and Drinking Water, Implementation guidance for the arsenic rule, EPA report816-D-02-005, Cincinnati, USA (2002).

[8] D. L. Guerra, C. Airoldi, V. P. Lemos, R. S. Angélica, R. R. Viana, Química Nova 31 (2008) 356.

[9] O. Altin, H.O. Ozbelge, T. Dogu, J. Colloid interface Sci. 198 (1998) 130.

[10] P. K. Jal, S. Patel, B. K. Mishra, Talanta 62 (2004) 1005.
[11] J. A. A. Sales, C. Airoldi, J. Non-Cryst. Solids 330 (2003) 142.

[12] D. Pavia, G. Lampman, G. Kriz, Introduction to spectroscopy, Harcourt College Publ., USA (2001).

[13] K. Kosuge, A. Tsunashima, Langmuir 12 (1996) 1124.

[14] D. Pérez-Quintanilla, I. Hierro, M. Fajardo, I. Sierra, Mater. Res. Bull. 42 (2007) 1518.

[15] D. L. Guerra, A. A. Pinto, C. Airoldi, Inorg. Chem. Comm. 11 (2008) 20.

[16] D. L. Guerra, V. P. Lemos, C. Airoldi, R. S. Angélica, Polyhedron 25 (2006) 2880.

[17] D. L. Guerra, C. Airoldi, S. K. Sousa, Appl. Surface Sci. 254 (2008) 5157.

[18] D. Karadag, Y. Koc, M. Turan, M. Ozturk, J. Hazard. Mater. 144 (2007) 432.

[19] B. Yu, Y. Zhang, A. Shukla, S. S. Shukla, K. L. Dorris, J. Hazard. Mater. 80 (2000) 33-42.

[20] N. Tekin, E. Kadinci, Ö. Demirbas, M. Alkan, A. Kara, J. Colloid Interface Sci. 89 (2006) 472-479.

[21] A. G. S. Prado C. Airoldi, Anal. Chim. Acta 432 (2001) 201.

[22] V. S. O. Ruiz, C. Airoldi, Thermochim. Acta 420 (2004) 73.

[23] O. A. C. Monteiro, C. Airoldi, J. Colloid Interface Sci. 282 (2005) 32.

[24] S. H. M. Evangelista, E. De Oliveira, G. R. Castro, L. F. Zara, A. G. S. Prado, Surface Sci. 601 (2007) 2194.

[25] A. G. S. Prado, C. Airoldi, Green Chem. 4 (2002) 288.

[26] J. A. A. Sales, A. G. S. Prado, C. Airoldi, Polyhedron 21 (2002) 2647.

[27] A. G. S. Prado, J. D. Torres, E. A. Farias, S. C. L. Dias, J. Colloid Interface Sci. 277 (2004) 43.

(Rec. 08/02/2009, Ac. 23/04/2009) 